Article

\title{
Pride, Paternalism, Prejudice-Images of the Working Class
}

\author{
Ove Skarpenes ${ }^{1, *}$ and Rune Sakslind ${ }^{2}$ \\ 1 Department of Sociology and Social Work, University of Agder, 4604 Kristiansand, Norway \\ 2 Department of Sociology, University of Bergen, 5020 Bergen, Norway; Rune.Sakslind@uib.no \\ * Correspondence: Ove.Skarpenes@uia.no; Tel.: +47-97-043-369
}

Received: 8 November 2017; Accepted: 3 January 2018; Published: 10 January 2018

\begin{abstract}
What has happened with the image of the working class? The hero in the construction of the Nordic Model was the labor movement (and the working class). For a long time, this was the dominant picture of the Norwegian working class. However, the societal trends of the past decades have, in a peculiar way, given the working class a central place in political discussions and in the public sphere, but now, a more ambivalent image emerges. In a somewhat paternalistic way, the worker image in political and academic debates as well as in part of the public sphere is typically that of a person unsuccessful in the educational system. Even a third image is identifiable in the public sphere-a prejudice imagery - in which the class is labelled as unhealthy, abusing the welfare system, culturally unsophisticated, and politically dangerous, moving toward right-wing populism. The ambition of the paper is to present these different images of the working class.
\end{abstract}

Keywords: Hero; drop-out; images; working class; unhealthy; immigration skepticism

\section{Introduction-National Cultures of Class Analysis}

One aspect of the renewed interest in class in various countries is the many efforts to re-examine critically the concept of class itself, including the theoretical and empirical methodologies inherited from traditional class analysis. ${ }^{1}$ As it turns out, this revival takes on forms and content that differs between countries. This fact points, in an indirect way, to the persistent influence of national factors in the construction of class and to the effect of national cultures in the work of interpreting class processes (Skarpenes and Sakslind 2018). Some common elements in this revival can be identified. First, we observe the abandoning of the causal paradigm where (economic) structures determine class consciousness (and eventually leads to political action). A point of reference was the book Working-Class Formation: Nineteenth Century Patterns in Western Europe and the United States (Katznelson and Zolberg 1986). Ira Katznelson emphasized that the proletarianization of class needed to be understood as national differences in the ties between economic, social, and political structures. The resolution of the "class in itself for itself" model and the specification of different levels of analysis made it possible to construct various cases of class formation (Katznelson 1986, p. 14). ${ }^{2}$ The new approach in working-class social history widened our knowledge on working-class formation in France, Germany, and the US. ${ }^{3}$ A parallel is found in British sociology, where David Lockwood delineated the

1 This movement is documented in a voluminous international literature about class analysis that took off as a trend in the middle of the 1990s. See, e.g., (Grusky and Sørensen 1998; Savage 2000; Devine and Savage 2005; Sakslind 2007).

2 On the "paradigmatic" role of the case of the English working class and a discussion of epistemological weakness of the Marxist class analysis, see (Somers 1997). The most sophisticated analysis of the working-class culture and the foundation of Karl Marx's theory is probably the historical sociological comparison between Germany and Britain, 1640-1914, in (Biernacki 1995).

3 In an impressive review of the European working class, Geary (2004) shows how the politics and the language of class emerged in Britain, France, and Germany before factory production became widespread (p. 116). The worker had 
workers in three different types (proletarian, deferential, and privatized). They originated in various working, geographical, and social environments, developed different occupational solidarity and community sociability, and drew different class boundaries. The three types had unequal sets of norms, values, ideas, and political outlooks, and they differed in their understanding of hierarchies; thus, they would not share a common consciousness (Lockwood 1975, pp. 16-30). Lockwood contributed with the development of these ideal types of workers to elaborate the "Structure-Consciousness-Action" (S-C-A) model, but he found it increasingly difficult to defend his own arguments and the S-C-A model. In the 80s and 90s, he distanced himself from class analysis (Savage 2000, p. 26). A second common element is the spread of a new and more pervasive interest in the middle class and its societal role, including its relationship to the working class and vice versa (for instance (Lamont 1994; Tim and Savage 1995; Kocka 1981, 1995; Zunz et al. 2002; Sakslind and Skarpenes 2014)). And third, the need for analysing culture as well as for theorizing in novel, "nonstructuralist" ways was acknowledged (Lamont 1994, 2000; Savage 2000; Bottero 2004; Devine and Savage 2005; Payne and Grew 2005; Savage and Bennett 2005). When it comes to the working class, many of the new proposals for research, in particular in the Anglo-American world, aim at the analysis of class as a more complex object: instead of searching for an unambiguous phenomenon, they try to map varieties of factual identities of workers in different labor markets, sectors of employment, occupations, regions, genders, and so forth. Instead of viewing class as a static reality, they look for its emergence and transformation under changing conditions, in a perspective more open to cultural heterogeneity, class ambivalence, or "dis-association" from class (Savage et al. 2001; Blackshaw 2013; Savage 2015). This brief review reveals the fact that class (and indeed the working class) is welcomed back on the international research agenda, but apparently not in Norway.

Oddly enough, workers as a class or as a collective have, until recently, been largely absent from Norwegian political discourse. Moreover, this class has not been the object of systematic analysis in the social sciences of modern Norway. This is a remarkable circumstance in a country "branding" the Nordic model in political as well as in academic spheres, where the often-portrayed hero in the construction of the model is the indigenous working class (Skarpenes and Sakslind 2018). The lack of social scientific knowledge about the Norwegian working class and their ways of living and thinking is strikingly when compared with the renewed interest in the working class in the media. In public debates journalists, novelists, politicians, columnists, social scientists, etc. participate in discussions without basic knowledge of how the class itself perceives education, work, culture, policy, immigration and so on. The paradox is this: there is growing interest in the working class, new images of the class are constructed and presented in the media discourse, but at the same time, there is an absence of interest in the views of this class itself. While we have been working with a large corpus of data on the Norwegian working class (focusing on education and lack of education, experiences in school, work, ambitions, class, family, status, leisure time, politics, and cultural preferences) this discrepancy has become urgent to express. We will address the class' views, opinions, critiques etc., on different topics in forthcoming publications, but in this paper we will present and discuss different images of the working class circulating in the academic literature and in the media discourse. Jones (2011) showed the demonization of the working class in British media discourse and by linking moralization and class identity, Le Grand (2015) argued that the moralization of the chavs entailed constructing them as a folk devil threatening the moral and the aesthetic order of the British society (Le Grand 2015, p. 9). We follow this line of inquiry focusing on the Norwegian working class. Our ambition is merely to present and discuss some examples of the different public images of the working class we have identified in Norway. Based on these examples, we launch the hypothesis that, in addition to a positive

different experiences and lived very different lives depending on nationality, religion, occupation, gender, and ethnicity. Confer also the contributions from Sewell Jr, Perrot, Kocka and Bridges in (Katznelson and Zolberg 1986), and for Britain, (Savage and Miles 1994). 
image of the working class, a more ambivalent and even a negative image seem to have emerged. However, further and more detailed empirical research is still needed to follow up such an hypothesis. ${ }^{4}$

\section{The Norwegian Working Class: Proud Hero in the Construction of the Nordic Model}

Still, images of the working class hero circulate in the newspapers. ${ }^{5}$ Even if the occurrence of the image of a "working class hero" in today's papers more often than not are referring to a fictive person (in a film or in a book), some decades ago, he/she was a real person. In contrast to the discipline of sociology, which seldom engages in a historical analysis (Inglis 2014), we will in the first part of this paper present findings from social and cultural history to map the emergence of the working-class hero in Norway. The history of Norwegian modernization is patterned by societal particularities, one of which is the position of the working class and its agency. The construction of the welfare state in Norway is conventionally pictured as a creation of the labor movement and as the successful result of its organizational strength, its reformism, and its class alliances with popular forces. One of the axes in this project has been the link between the Labor Party (DNA) and the Trade Union Movement (LO), while the other axis is the link between the Union and the workers as constituted by the system of collective bargaining. A class compromise between employees and employers (as equal partners) in collective bargaining was in place already in 1907 and further strengthened in the 1930s (a second compromise), resulting in a national collective agreement concerning wages and working conditions (Olstad 1991). This agreement entailed a regulated relationship between the employers and employees concerning their duties and rights, wages, and working conditions. It is not uncommon to see this system for collective bargaining as the backbone of the Norwegian model and a necessary condition for the "smooth" integration of social democracy in a liberal bourgeois society (Olstad 1991; Sejersted 2005; Berntsen 2015; Olsen 2015). The element that closed this circuit of power for decades was the class voting of the single worker in elections, in his or her preferences for either the DNA or other political parties on the left. For many years the historians' response to these hegemonic facts was to focus on the political or ideological controversies within the labor movement. This scholarly tradition left the impression of a rather "politicized" worker's figure, ${ }^{6}$ and according on the status they assigned to the labor movement, they portrayed the working class (implicitly) as one of the heroes of Norwegian modernity. In terms of class structure, Norway was peripheral at the time of the establishment of its modern constitution (1814), ${ }^{7}$ that is, it was a society without a traditional, land-owning nobility and cultural aristocracy. Instead, a tiny elite of civil servants and clergymen ruled in a society dominated by agriculture, forestry, and fishing and with a population consisting of an overwhelming majority of peasants (freeholders and cotters). Internally, this dominating class segment was only weakly stratified, thus representing a social structure with a rather egalitarian profile. This profile is also echoed in the petit-bourgeois character of Norwegian economic modernization. The core group in the emerging capitalism was the small owners and entrepreneurs in industry, trade, and commerce,

4 Our approach is explorative. We have used google and searched on "social class" and combined it with different traits. We have used google to find different texts and media reports (academic journals, newspapers, tv and radio, blogs, social media, commercials, etc.). We could have used the media archive Atekst. The archive contains printed newspaper original editions of national, regional, and local newspapers as well as a variety of magazines and journals. But we wanted to include other texts as well. In the analysis, we discuss example of different images of the working class and we present hypothesis. Our paper should be considered as a first step. More detailed analysis is needed.

5 A google search on working-class hero ("arbeiderklassehelt") gave 507 hits 9 December 2016 and 370 hits 15 March 2017. An overview of the 10-20 first articles show that hits (in newspapers, radio, and paragraphs in books) mostly refer to a working class hero in a book, movie or in the lyric of song. One article is about the Minister of Finance in the US, Steven Munchin (not a working-class hero), and one is about Bruce Springsteen (a kind of working-class hero). One personal blog has the following heading: "I am a working-class hero" (Jeg er en arbeiderklassehelt). We did not find articles describing the work and life of an ordinary working-class person.

6 This is a circumstance only recently balanced by social historians that emphasize the heterogeneity of the working class, by exploring labor processes in different trades, skill hierarchies, local cultures, and everyday life. A prominent work of this caliber is (Bjørnson 1990).

7 Historians describe this political constitution as the most democratic in Europe at the time. 
a class that put its permanent stamp on Norwegian society and institutions, and in the image of the historian Sejersted, they are the backbone of a peculiar "democratic capitalism" that distinguishes the Norwegian Sonderweg (Sejersted 1993). The resulting social formation, characterized by a vital petite bourgeoisie but with a weak class of (grand) capitalists, left a vacuum for entrepreneurial interventions in the economic sphere that could only be filled by an active state. The Norwegian development, as led by the Labor Party, was based on the political support of a well-organized class of workers (in terms of trades as well as in political loyalties), in industry, construction, transport, public sector, etc. The process of industrialization resulted in the creation of a relatively homogeneous working class with respect to social and economic status as well as to organizational and cultural features (Sakslind et al. 1985).

The class grew out of an egalitarian society, mainly with a developed primary sector of the economy (agriculture, forestry, and fishing), and for many workers, employment in industry meant better living conditions and an upward, rather than downward, social mobility. In contrast to the expropriation of workers from the countryside in Britain, small communities were preserved in Norway and large group of workers (up to the 1960s) combined small-scale agriculture and/or small-scale fishing with industrial work (Brox 2016). Thus, the workers were harmoniously integrated in society and gave rise to the development of the social democratic order (Sejersted 2005). The regionally dispersed pattern of industrialization (combined with the low average size of the companies) created a pattern of recruitment that made the socio-cultural boundaries between small farmers, small-scale fisheries, and industrial workers, as well as between craftsmen and skilled workers, rather weak and unclear. The designation "worker" tended to encompass all manual laborers both in the primary sector and in the industry as well as artisans, and this broad definition was later to be fortified by the Labor Party's politics of class alliances. ${ }^{8}$ Thus, the relative homogeneity of the Norwegian working class is primarily due to equality in living conditions and social status within a society not marked by strong class features-a generic type of equality that does not necessarily give rise to a clearly defined class identity. ${ }^{9}$ During most of the 20th century, this socio-economic and general cultural identity of Norwegian workers was consolidated on the basis of a habitus formed by practical work experience, with minor cultural (and economic) differences between skilled and unskilled workers. Until 1994 Norway lacked a complete system of vocational education combining apprenticeship training and school-based courses put in place, a fact which implies that only the youngest cohorts of the working class can be expected to have an identity influenced by the culture of technology. In Norway, and in other Western countries, the 20th century has brought a radical deindustrialization of the labor force. Hence, the traditional segment of the labor force employed in manufacturing, carrying a certain ideological hegemony in the labor movement, today constitute less than $10 \%$ of the labor force. ${ }^{10}$ Still, estimates based on broader definitions of what constitutes a wage worker, in all sectors of employment, indicate that the working class remains a significant social segment in Norway (a little less than 50\%). ${ }^{11}$ Defining as "workers" all those who are wage laborers and without education

8 In spite of the conflicts of interest between the various trades and industries, the emerging national unions had an integrating effect on the working class.

9 For example, compared to the German working class in its formative period (see Kocka 1981).

10 Statistics Norway (2016) found that "plant and machine operators and assemblers" made up 6.2\% of the labor force in 2015. Available online: http:/ / www.ssb.no/arbeid-og-lonn/statistikker/aku/kvartal/2016-10-27? fane=tabell\&sort= nummer\&tabell $=282262$ (accessed on 25 November 2016). 5.3\% are placed in "Other occupation" and some of these might be unqualified workers in industrial production.

11 In 2015, Statistics Norway reports employments by occupation: Managers 7.7\%, Academic occupations (professions etc.) $26.8 \%$, college university occupations (nurses, social workers, kindergarten and primary school teachers, etc.) $17 \%$. In sum $51.5 \%$ of the employed had higher education. The rest (office occupations $5.9 \%$, sale- and service $19.9 \%$, farmers and fishermen $1.9 \%$, craft $9.3 \%$, industry $6.2 \%$ and other occupations $5.3 \%$ ) add up to $48,5 \%$. Available online: https: //www.ssb.no/264147/sysselsatte-15-74-ar-etter-kjonn-og-yrke.arsgjennomsnitt.prosent (accessed on 25 November 2016). 
beyond secondary school could bring this figure up to a higher level (Skarpenes and Sakslind 2018). ${ }^{12}$ Moreover, developments of the 20th century, including the oil economy, has provided many wage workers in Norway with an unprecedented, and world-leading, level of material wealth. The labor movement in Norway was not only a political project: for many of its leaders, it was also a program for educating the worker, to give him ${ }^{13}$ dannelse (Bildung), to create a new human being. This meant stripping off his irresponsible, preindustrial habitus of the "day-worker culture" and to turn him into the disciplined, enlightened, self-reliant, and independent worker in the imagery of the "culture of the skilled worker" (Olstad 1991; Kjeldstadli 1996), or the respectable worker (Bjørnson 1990, p. 121). This educational project had the practical work of organizing as one of its main activities, something that extended beyond the union domain (in its narrow sense) and meant the manifestation of solidarity on the shop-floor level as well as in local communities. Its spirit was that of bringing social uplift, and its result was a great accomplishment in collective social mobility for the Norwegian working class. In our view, Norwegian modernization during the 20th century meant the building of egalitarian institutions promoting egalitarianism as a culture. In principle, they kept the emerging society open for the lower classes. The construction of the unified (primary) school (enhetsskolen) (1920) exemplifies this: in terms of structure, by the incorporation of all social classes, and by the postponement of meritocratic tracking. In terms of culture, by education policies that systematically modified and down-graded professional and academic ambitions by appealing to "populist" values (Lauglo 1995). A succession of reforms during the 20th century has meant the expansion of this culture to the secondary school, and its profile has been emulated in the social-pedagogical reforms of recent decades (Skarpenes 2007a). ${ }^{14}$

Our interpretation is that the success of the labor movement has established a heroic picture of the working class (implicit in the narratives in both the discipline of history and sociology). The class (as an organizational movement) was politically successful for 50 years with social democracy, and the class was the main force in the construction of the Nordic Model characterized by full employment, collective bargaining, salary flattening, unified school, and universal welfare rights.

\section{The Norwegian Working Class: Educational and Occupational Failure?}

There seems to be an ongoing change of the working-class image in the public debate, in a process where social science and political argumentation are mixed and intertwined, gradually affecting our perception of the working class. In the political debate, parties agree on the importance of higher education. The earlier we intervene in order to "produce" future educational success, the better, and a new regime of control and testing is implemented in kindergarten and in primary school (Pettersvold and Østrem 2012). Early intervention and the new regime of testing are legitimized with a compromise between solidarity (we need to test in order to help everyone at their own level) and the OECD mantra of economic competitiveness (a well-educated population equals national economic success). The emerging imagery is one in which a life without higher education turns out to be undesirable and almost shameful. Those leaving school early, no matter the reason, are registered as drop-outs, and this classification or category constitutes a group that is increasingly being in danger of stigmatizing by being categorized. ${ }^{15}$ The classification of people might affect the behavior of the people

12 Statistic Norway reports that in $2015,71.2 \%$ of the male-and $64.4 \%$ of the female population had no further education than upper secondary school or a certificate of apprenticeship. Available online: http://www.ssb.no/utdanning/statistikker/ utniv (accessed on 25 November 2016).

13 In the period described, the worker category is predominantly a male figure.

14 While the pervasive presence of egalitarian values in Norwegian society is a rather uncontroversial assertion, the question of the precise nature of this cultural structure and its wider implications remains to be examined. This includes the question of how equal in terms of power and material resources this society in fact is in a comparative perspective.

15 A google search on "sosial klasse + frafall i skolen" (social class + dropping out of school) gave 173,000 hits 30 March 2017. The first 10-20 hits include research articles and reports, master thesis, articles in newspaper, articles in encyclopedias, statistics from The Norwegian Directorate for Children, Youth and Family Affairs and Statistics Norway, reports from municipalities, unions, Red Cross and there is a reference to The House of Literature in Bergen and the arrangement "Gutter, frafall og klasse" ("Boys, drops-out and class"). We learn from these texts that drop-out is a huge societal problem. Boys from 
classified, and when categories are activated in practices a process of "making up people" is going on (Hacking 2004, p. 104). It seems to be a tendency that drop-outs are being "made up" by politicians, statisticians, and social scientists (Skarpenes and Nilsen 2014). The inevitable implication is a heavy normalization of the necessity of educational attainment, at least at the high-school level. Hardly a week passes in Norwegian media without a public discussion about early intervention, drop-outs, school test, mapping of skills in kindergartens, and so forth, and the discussions are often informed by findings from social science concerning class differences. It should not come as a surprise that social science affects the images of the working class (and thus perhaps also their view of themselves). Social science is "the bad conscience" of the welfare state (Mjøset 1991, p. 155), identifying deficiencies in welfare institutions. With good intentions to expose injustices in society, decades of dissemination of the perspective of "social reproduction of educational inequality" in sociology have established as an indisputable fact that the probability of "success" in education increases when your parents are placed high in the social hierarchy. Generations of students in social studies have been taught these lessons about social reproduction of inequality. The analysis has provided vital knowledge, but simultaneously, the thesis of reproduction might have unintended consequences. Only rarely does the sociology of education connect with the sociology of work and vocational training. Research combining sociology of work with sociology of education shows that reproduction of working-class occupations within families should rather, or at least also, be interpreted as a reproduction of vocational and occupational pride, a longing for fellowship and solidarity (Olsen 2008, 2011, 2012). It is not seldom that children with working-class backgrounds actually want a life and occupation like their parents (Bjørnstad 1997; Seljestad 2003; Vogt 2007; Skilbrei 2010; Borgen and Skogen 2013). In some areas with a strong working-class culture, pursuing occupational mobility was for a long time considered to be a class betrayal (Lysgaard 1985). In order to disclose the class' different (and unjust) life chances, social reproduction within the working class is often understood either as forfeited opportunities of upward mobility, short upward mobility or as an unused reserve of intelligence and talent. (In this type of discourse a latent meaning seems to be that a working-class life is not a good-enough life or is even an alienated life in "false conscience" or "misrecognition." As has been pointed out by Hagen, some Norwegian sociologists go far in describing a working-class life as a bad life (Hagen 2016).

The reality is that this is unexplored terrain that we do not know much about, and the (Norwegian) discipline of sociology lacks even elementary knowledge about the workers' own assessments of their lives. This means that what sociocultural status the facts of "reproduction" or "mobility" have in the minds of Norwegian workers and in working class families is an open question. ${ }^{16}$ The situation invites sociology to reproduce conventional images of class-including its eventual middle-class prejudices-instead of providing new knowledge. This is by no means a Norwegian peculiarity: The historian (with a working-class background) Harold Perkin reminded us that "what the English working class most needs to be rescued from is the enormous condescension of middle class intellectuals" (Perkin 1978, p. 87). Lynch and O' Neill provided a reminder when pointing to the danger that "the inequalities experienced in the educational system by working class people has been colonised by middle class academics" (Lynch and O'Neill 1994, p. 307). So, when sociologists argue that working-class people are judged by middle-class values and norms (Reay 1998), we should be increasingly aware that the norms and the societal images might originate in the sociological literature. The sociological and political critique may therefore both reveal structural injustices and

working class backgrounds in vocational education are overrepresented among the drop-outs. But the story is even more complex. A search on "sosial klasse + høyere utdanning" ("social class + higher education") gave 220,000 hits 30 March 2017. The first 10-20 hits contain research articles, books, reports from Statistics Norway and the Union, newspapers, etc. It is the story of social reproduction that is told. The normative subtext in the social reproduction story is, of course, that social mobility should increase in order to obtain a more democratic society. The unintended consequence is a never-ending construction of people without long education as losers or persons with unfulfilled potentials.

16 The exception is Skilbrei's research on working class women, and some of them argue that the culture of the working class, i.e., feelings of collectivity and shared values are more important for them than social mobility (Skilbrei 2010). 
simultaneously stigmatize those who actually choose another occupation and another life than that of the middle class. The imagery of the working class in this literature seems not that of a hero but rather of a repressed worker who, because of educational failure, ended up in a working-class occupation without abilities to climb the ladder or being blocked in his or her attempts to do so. We do not have hard data to support the argument, but we still might launch a hypothesis that there is an ongoing process in which political, scientific, and journalistic arguments and values mingle and mix and establish what can be called the paternalistic narrative. The narrative or the values associated with it are embedded in the working-class culture and sometimes influence the class's (especially women) perception of itself (Skarpenes and Sakslind 2018). We know from a classical study of women in the working class in Britain that feelings of inferiority are present, in the sense that shame and a desire to appear respectable is common (Skeggs 1997). There are findings pointing to a change in the self-perceptions of women workers in Norway. Some women in health and services seem to be angry, exasperated and even sad (but not shameful and servile as in Britain).

The habitus of this group seems to have changed when compared to the same cohort in an earlier investigation: in her study of working-class women in the 70s and early $80 \mathrm{~s}$ in Norway, Hoel (1983) showed the collective pride among women entering paid work during those years. They were acquiring their own job and their own money. This generation of women entered service and health occupations. Many of these occupations were newly established in the occupational structure in the welfare state, and several of them also resembled the servant professions that existed before the housewife era (approximately 1940-1980) in Norwegian history: that is, maids in private homes, servants, and farm girls and boys. In the welfare state, some of these tasks became part of the occupational structure, albeit in far more settled conditions, but at the same time, the work is still poorly paid and "servant-like" (cleaning, cooking, serving food, and working as a cashier). Where Hoel mainly identified pride in her study of women from the 80s, we can register, in addition to pride, a certain resignation and anger among some of these women, as a response to their placement at the lower end of the occupational hierarchy. (Skarpenes and Sakslind 2018)

\section{The Norwegian Working Class: Unhealthy, Right-Wing, Culturally Unsophisticated Social Clients?}

We know that education, income, and occupation correlate with health. If you are in the group with high education, you are statistically in much better health than if you do not have a long education and high income. Mortality rates differ accordingly. People with high education and income live up 10 years longer than people with low education and income (Elstad 2005). ${ }^{17}$ When important findings like these find their way into the public debate, the danger is that they transform into stigmas in our time. In his analysis of the media discourse, Owen Jones traces a new "demonization" of the working class in Britain back to the Thatcher era (Jones 2011). Moralization is performative in constructing class identities, and chavs have been cast as "non-respectable" white working-class "folk-devil" (Le Grand 2015). No equivalent research exists in Norway, but our impression is that some of the same arguments and values are traceable in Norwegian media as well. Maybe a third image is

17 A google search on "Den usunne sosiale klassen" (the unhealthy social class) gave 97,400 hits. (15 March 2017). The first 10-20 hits include for instance research articles and reports, two bachelor theses, articles in newspapers, reports. The Norwegian Directorate of Health, a report from a County Council municipalities. The story told or image constructed is basically this: obesity is linked to low socio-economic status. The social pattern is that low social class means no exercising, smoking, unhealthy diet, early death, etc. The unintended consequence (of the good intentions in pointing at these socially constructed inequalities) is the image of an unhealthy (pathetic even) working class. A search on "den trygdede sosiale klassen" (the class on social benefits") (84,000 hits, 15 March 2017) will inform the reader that it is people from low social class who receive benefits, they are fatter, sicker, etc. They use and abuse the welfare system. A search on "den høyrepopulistiske sosiale klassen" ("the rightwing populist social class") gave 4610 hits. The first 10-20 hits include research articles, articles in newspaper, articles in encyclopedias, comments from political parties. Some of the contribution discuss the reasons behind the new rightwing working class. 
emerging in the public sphere-a prejudice imagery—in which it might be more acceptable to label the class (a) unhealthy, (b) abusing the welfare system, (c) right-wing, and (d) culturally unsophisticated. First, it seems to be more legitimate than before to participate in the construction of an image of a smoking and often fat working class. ${ }^{18}$ Second, the working class, or rather persons evidently meant to represent (or originated from) the working class, is sometimes portrayed as living on social benefits. ${ }^{19}$ This is a group who allegedly exploits social benefits (the people are so called "navere"). ${ }^{20}$ The members of the group are often young men from lowly educated families. Not infrequently, these youth struggle with drug abuse and/or mental-health problems. In addition, the media discourse is characterized by statistics showing that sick leave in Norway is one of the highest in Europe, and it is especially women in the health sector who push the numbers upward. ${ }^{21}$ It is seldom explicitly stated, but this story of the working class has connotations that might make us think of members of the class as freeloaders on the welfare state that they themselves created. When this story is implicitly told, there is a constant risk of taking part in a stigmatizing practice. Turning to point c, perhaps the most dramatic role given to the working class in contemporary Norway is (as indicated in studies of voting behavior) to be the electoral backbone of the Progress Party (FrP) (Fremskrittspartiet) and the seedbed for currents of "rightist populism" (Bjørklund 2007). Political sociology's idea of "the end of class voting" tends to use traditional left-wing ideology as the yardstick for measuring an evaporating essence of class "consciousness," implying that the main object of change has been working class culture, and not party politics. Instead, the most credible hypothesis on this change is that it is the product of processes on the level of "class" as well as in "politics" (Bjørklund 2008). Bjørklund (2007) shows the complexity within FrP. In the western parts of Norway FrP has recruited voters from the liberal party (Venstre in Norway) vegetating on the old counter-cultural values of the rural-egalitarian people against the urban elites, while in important industrial parts of Norway, FrP, claims to be the new Labor party (Arbeiderpartiet in Norway), while in some rich places in the eastern part of Norway, FrP tries to create an image of itself as the new conservative party (Høyre in Norway) (Bjørklund 2007, p. 165).

In addition, there seem to be a constructed an image of a culturally unsophisticated working class. However, the relations between cultural taste and class belonging are complex in the egalitarian Norway. Norway is still characterized by an anti-intellectualism that is often mobilized in cultural discussions. There seems to be a widespread practice, even within the highly educated middle class, that its representatives often convert cultural judgments to moral judgments (Skarpenes 2007b; Sakslind and Skarpenes 2014). When asking the educated middle class to compare and rank different writers, they hesitate to do so, because, as they say, if you say that one author is better than the other, you judge the person who likes that author as a better person than the one who likes the other (Skarpenes 2007b). These findings suggest that moral judgments often trump cultural judgments in an egalitarian culture. The Norwegian national culture is loosely bounded, and the cultural boundaries are too blurred to meaningfully speak about any (institutionalized) elitist intellectual culture (neither highbrow nor omnivore) in the same way as that presented in France, England, and Germany (Danielsen 1998; Daloz 2007; Skarpenes 2007b; Haarr and Krogstad 2011; Gujord and Vassenden 2015). In a comparative perspective, the Norwegian cultural configuration emerges with other characteristics (Daloz 2007, 2009; Sakslind and Skarpenes 2014). The media's present depiction of the worker is in a curious and indirect way influenced by sociological stereotypes, in the sense that it resembles an inverted (negative) copy of the virtues attributed to some of the (Norwegian) elites. As a counterpoint, (and again we need hard data to support our impressions) the worker

18 At one point the former major in Oslo recommended "east-enders" to learn a healthier living form "west-enders". Available online: https://www.nrk.no/ostlandssendingen/ber-ostkanten-laere-av-vestkanten-1.3799687 (accessed on 9 December 2016).

19 See Asle Toje's comment in Morgenbladet. Available online: https:/ / morgenbladet.no/ideer/2016/07/asle-toje-hvite-niggere (accessed on 9 December 2016).

20 It is even a verb “å nave”. A google search on “å nave” (19 June 2017) gave 345,000 matches.

21 (http://noa.stami.no/arbeidsmiljoindikatorer/helseutfallarbeidsskader/sykefravar/legemeldt-sykefravar/). 
image in the public sphere is more often one of the fast-food eating, excessively drinking person (most often a male, for instance on holiday on the Canary Islands), watching reality TV, reading pulp-fiction (if reading at all), crying out for lower petrol prices, etc. Our hypothesis is that the backstage for this is that an agenda of "cultural" issues (immigration, lifestyles, and identity politics) has dominated the public sphere, displacing traditional issues of democracy, power, and economic distribution in the eyes of some observers leading to a growing tension between the working class and segments of the middle classes. The recent, and tremendously successful, biographical novel of Edouard Louis En finir avec Eddy Bellegueule (translated to Norwegian-Farvel til Eddy Belleguele, (Louis 2015)) tells the story of an educated successful man entering the upper-middle class in Paris, leaving behind the dirty, violent, homophobic, and xenophobic working class in the regional periphery. Without doubting his painful experiences, the novel, some writers and journalists argued, cannot help participating in the demonization of a white working class. ${ }^{22}$ It is discussed whether the public debate following this kind of books and journalistic reportage from working-class areas (benefits porn) could dissolve the respectability that the working class gained during most of the last century. A recent Norwegian example could be the short stories in the book Arbeidsnever ("Working Hands") by Dale (2016). He reports to have had a working class upbringing and for some years he had uninspiring manual work in a brewery. He left his job and hometown for studies in a bigger city and he even attended a school for writers (Skrivekunstakademiet). In his book, he writes about distinctions. Friends met for weekend in a cabin. The persons who left for further education want to eat lamb shank and drink exotic beer and Cava, while those who didn't leave the hometown to study are happy with home-made pizza and a six-pack of beer from the local store. The reviewers ${ }^{23}$ (who more often than not seem to have some knowledge about the sociology of distinctions) identified a class analysis. But since the left-behind working class themselves have not been interviewed (we read the educated writers' story), we are at risk of being left with stereotypes and potential reproduction of myths. Does the lamb shank really make these working-class men feel inferior? Do they care at all? Maybe they even feel embarrassed on behalf of those who (according to the writer) no longer find homemade pizza an appropriate dinner on a Friday night at the cabin? What are the social implications of the distinctions? The reader is informed by the educated writer's view of the left behind uneducated friends, not the views of the uneducated themselves.

It is also interesting to notice the receipt of Cathrine Evelid's books. She writes novels about working class people in non-urban areas. Her novels are highly appreciated by literary critics and the reviewers describe the content of the books as sad, dark, hopeless, etc. ${ }^{24}$ However, the writer herself does not at all regard the lives of the characters as sad or hopeless. ${ }^{25}$ On the contrary she insists on the ordinariness of her characters. She writes about people living in the 70s and 80s having normal lives working in the oil sector in the North Sea, in a gas station, or in a cafeteria. Not long ago, the image of the people Evelid (2016) describes would be that of ordinary working class people, sometimes heroic characters in our society, but they are now portrayed as sad and hopeless.

22 That was Kjartan Fløgstad's argument (a Norwegian writer). Some writers and columnists agreed and some did not. The discussion went on in different papers and media. Part of the discussion can be found in the paper Morgenbladet. Available online: https://morgenbladet.no/ideer/2016/05/tung-symbolsk-vold-flogstad (accessed on 1 December 2016), see also Fløgstad (2016).

23 For instance, Available online: http:/ / www.aftenposten.no/kultur/Jan-Kristoffer-Dale-Sympatisk-bilde-av-arbeiderklassen604540b.html (accessed on 9 December 2016).

24 Her latest novel Drømmer fra Texaco (2016) was reviewed as sad by Leif Ekle in NrK. Available online: https:/ / www.nrk.no/ kultur/bok/ameldelse-av-_drommer-fra-texaco-av-cathrine-evelid-1.13146919 (accessed on 11 December 2016).

25 Listen to the interview with her at Nrk "Kulturhuset bok", 13.12.16, at 06.03. https:// radio.nrk.no/serie/kulturhuset-bok/ MKTR07010316/11-12-2016. 


\section{Conclusions}

While working with a large corpus of data on the Norwegian working class, we became aware of what seem to be the existence of different images of the working class. These different images coexist in the Norwegian public discourse. First, there is an image of the working class as a heroic figure in the construction of the welfare state. Second, we put forward the hypothesis that a new image has emerged in which the worker is seen as repressed, being an educational failure who ended up in a working-class occupation without abilities to climb the ladder, or being blocked in his or her attempts to do so. We even suggested the existence of third image—a prejudice imagery—in which it might be (explicitly and/or implicitly) acceptable to label the class as unhealthy, abusing the welfare system, right-wing, and culturally unsophisticated. In this image, the members of the working class constitute a group impending menace to the egalitarian state formation. Since the argument presented here are based on unsystematic readings of academic texts and newspaper articles, we hesitate to draw any conclusion. Our ambition has been to formulate some hypothesis. Further research is needed along these lines:

Discussions of the working class in the media have increased in number after Brexit and Trump's victory. But we need systematic analysis about how pictures of the working class are constructed in different contexts. It is important to show similarities and differences between the media coverages of the working class cross-nationally. Indeed, the public discourse is embedded in national cultures and we have just briefly presented some hypothesis about the "Norwegianness" (or Sonderwege) of the images of the Norwegian working class.

In addition, it is important (for Norwegian sociology) to follow the international research on the working class. There is a deficit of basic, factual knowledge about the moral universe of Norwegian workers and their ways of thinking. We still need to establish the content of the common cultural code of the working class in Norway by mapping workers attitudes toward the elites, the middle class, the immigrant, and the welfare state, education and social mobility, and cultural taste.

Acknowledgments: The authors are grateful to Roger Hestholm for his contributions to our many discussions. We would like to thank the two anonymous reviewers and the editors. University of Agder has covered the costs to publish in open access.

Author Contributions: Both authors contributed equally.

Conflicts of Interest: The authors declare no conflict of interest.

\section{References}

Berntsen, Harald. 2015. 'Det “Norske" Klassekompromisset'. Tidsskriftet Rødt! no. 3. Available online: http:/ / marxisme.no/category/2015/nr-3-2015/ (accessed on 25 August 2016).

Biernacki, Richard. 1995. The Fabrication of Labor. Germany and Britain 1640-1914. Berkeley: University of California Press.

Bjørklund, Tor. 2007. Fremskrittspartiets suksess og kulturell standardisering. Nytt Norsk Tidsskrift 23: 151-68.

Bjørklund, Tor. 2008. Arbeiderklassetilhørighet i Norge fra 1965 til 2001. Sosiologisk Tidsskrift 16: 341-61.

Bjørnson, Øyvind. 1990. På Klassekampens Grunn (1900-1920). Arbeiderbevegelsens Historie i Norge. Oslo: Tiden Norsk Forlag.

Bjørnstad, Tor. 1997. "Det er Litt Gøy Når du Merker at Du Kan Noe": Erfaringer fra Skolen og Orienteringer til Arbeidslivet Blant Elever På Elektrofag Og Rørfag vk1', AHS Serie A 1997-3. Bergen: AHS—Gruppe for Fleirfagleg Arbeidslivsforsking, Universitetet i Bergen.

Blackshaw, Tony. 2013. Working-Class Life in Northern England, 1945-2010: The Pre-History and after-Life of the Inbetweener Generation. London: Palgrave Macmillan.

Borgen, Olav Årstad, and Ketil Skogen. 2013. Gutta på jakt. Jakt som arena for reproduksjon av arbeiderklassekultur. Tidsskrift og Ungdomssforskning 13: 3-30.

Bottero, Wendy. 2004. Class Identities and the Identity of Class. Sociology 38: 985-1003. [CrossRef]

Brox, Ottar. 2016. På Vei mot et Postindustrielt Klassesamfunn? Oslo: Pax Forlag.

Butler Tim, and Mike Savage, eds. 1995. Social Change and the Middle Classes. London: UCL Press. 
Dale, Jan Kristoffer. 2016. Arbeidsnever. Oslo: Kolon forlag.

Daloz, Jean-Pascal. 2007. Political Elites and Conspicuous Modesty: Norway, Sweden, Finland in Comparative Perspective. Comparative Social Research 23: 173-212.

Daloz, Jean-Pascal. 2009. The Sociology of Elite Distinction: From Theoretical to Comparative Studies. Basingstoke and New York: Palgrave-Macmillan.

Danielsen, Arild. 1998. Kulturell kapital i Norge. Sosiologisk Tidsskrift 6: 75-106.

Devine, Fiona, and Mike Savage. 2005. The Cultural Turn, Sociology and Class Analysis. In Rethinking Class: Culture, Identities and Lifestyles. Edited by Fiona Devine, Mike Savage, John Scott and Rosemary Crompton. Basingstoke: Palgrave Macmillan, pp. 1-23.

Elstad, Jon Ivar. 2005. Sosioøkonomiske Ulikheter i Helse Teorier og Forklaringer. Oslo: Sosial og helsedirektoratet. Oslo: Sosial og helsedirektoratet.

Evelid, Cathrine. 2016. Drømmer fra Texaco. Oslo: Aschehoug.

Fløgstad, Kjartan. 2016. Etter i Saumane. Kultur og Politikk i Arbeidarklassens Hundreår. Oslo: Gyldendal Norsk Forlag.

Geary, David. 2004. The European Working Classes in the Late Nineteenth and Early Twentieth centuries. In The European Way. European Societies in the 19th and 20th Centuries. Edited by Hartmut Kaelble. New York and Oxford: Berghahn Books.

Grusky, David B., and Jesper B. Sørensen. 1998. Can Class Analysis Be Salvaged? American Journal of Sociology 103: 1187-234. [CrossRef]

Gujord, Heming, and Anders Vassenden. 2015. Litterære distinksjoners brysomhet. In Hva Har Oljen Gjort Med Oss? Økonomisk Vekst og Kulturell Endring. Edited by Nils Asle Bergsgard and Anders Vassenden. Oslo: Cappelen Damm Akademisk.

Haarr, Tone Knutsen, and Anne Krogstad. 2011. Myten om den norske kultureliten. Sosiologisk Tidsskrift 19: 6-28. Hacking, Ian. 2004. Historical Ontology. Cambridge and London: Harvard University Press.

Hagen, Roar. 2016. Falske Positive? Kritikk Uten Alternativer. Available online: http:/ /sosiologen.no/2015/12/ falske-positive-kritikk-uten-alternativer/ (accessed on 25 August 2016).

Hoel, Marit. 1983. Den Kvinnelige Arbeiderklassen. Oslo: Universitetsforlaget.

Inglis, David. 2014. What is Worth Defending in Sociology Today? Presentism, Historical Vision and the Uses of Sociology. Cultural Sociology 8: 99-118. [CrossRef]

Jones, Owen. 2011. Chavs: The Demonization of the Working Class. London: Verso.

Katznelson, Ira. 1986. Working-Class Formation: Constructiong Cases and Comparisons. In Working-Class Formation. Nineteenth-CenturyPatterns in Western Europe and the United States. Edited by Ira Katznelson and Aristide Zolberg. Princeton: Princeton University Press, pp. 3-41.

Ira Katznelson, and Aristide Zolberg, eds. 1986. Working-Class Formation. Nineteenth-CenturyPatterns in Western Europe and the United States. Princeton: University Press.

Kjeldstadli, Knut. 1996. Historiens gang fra barbari til sivilisasjon-Gustav Johnsen ser seg tilbake. Arbeiderhistorie (Årbok for Arbeiderbevegelsens Arkiv og Bibliotek), 5-23.

Kocka, Jürgen. 1981. Class formation, interest organisation, and public policy: the origins of the German white collar class in the late nineteenth and early twentieth centuries. In Organizing Interests in Western Europe. Edited by Suzanne Berger. Cambridge: University Press.

Kocka, Jürgen. 1995. The Middle Classes in Europe. Journal of Modern History 67: 783-806. [CrossRef]

Lamont, Michèle. 1994. Money, Morals, and Manners. The Culture of the French and American Upper-Middle Class. Chicago: The University of Chicago Press. First published 1992.

Lamont, Michèle. 2000. The Dignity of Working Men. Morality and the Boundaries of Race, Class and Immigration. New York: Russell Sage Foundation at Harvard University Press.

Lauglo, Jon. 1995. Populism and Education in Norway. Comparative Education Review 39: 255-79. [CrossRef]

Le Grand, Elias. 2015. Linking Moralisation and Class Identity: The Role of Ressentiment and Respectability in the Social Reaction to 'chavs'. Sociological Research Online, 1-15. [CrossRef]

Lockwood, David. 1975. Sources of variations in working-class images of society. In Working-Class Images of Society. Edited by Martin Bulmer. Ipswich: Routledge \& Kegan Paul, pp. 16-30.

Louis, Edouard. 2015. Farvel til Eddy Bellegueule. Oslo: Aschehoug.

Lynch, Kathleen, and Cathleen O'Neill. 1994. The Colonisation of Social Class in Education. British Journal of Sociology of Education 15: 307-24. [CrossRef] 
Lysgaard, Sverre. 1985. Arbeiderkollektivet: En Studie i de Underordnedes Sosiologi. Oslo: Universitetsforlaget.

Mjøset, Lars. 1991. Kontroverser i Norsk Sosiologi. Oslo: Universitetsforlaget. Oslo: Universitetsforlaget.

Olsen, Ole Johnny. 2008. Institusjonelle Endringsprosesser i Norsk Fag-og Yrkesutdanning. Fornyelse Eller Gradvis Omdannelse? Bergen: Rokkansenteret.

Olsen, Ole Johnny. 2011. Yrkesutdanning i det moderne. Noen begreper til fortolkning av endringsprosesser i norsk fag- og yrkesopplæring. Sosiologisk Tidsskrift 19: 29-47.

Olsen, Ole Johnny. 2012. Yrkesfagenes status_Et spørsmål om innbyrdes forhold mellom arbeid og utdanning. En kommentar med en komparativ og historisk tilnærming. Søkelys på Arbeidslivet 29: 369-81.

Olsen, Ole Johnny. 2015. 'Sosialdemokratiet og Arbeiderklassens Integrasjon i det Borgerlige Samfunnet'. Tidsskriftet Rødt! no. 4. Available online: http:/ / marxisme.no/category/2015/nr-4-2015/ (accessed on 25 August 2016).

Olstad, Finn. 1991. Arbeiderklassens Vekst og Fall. Hovedlinjer i 100 Års Norsk Historie. Oslo: Universitetsforlaget.

Payne, Geoff, and Clare Grew. 2005. Unpacking 'Class Ambivalence': Some Conceptual and Methodological Issues in Accessing Class cultures. Sociology 39: 893-910. [CrossRef]

Perkin, Harold. 1978. The condenscension of posterity: The recent historiography of the English working class. Social Science History 3: 87-101.

Pettersvold, Mari, and Solveig Østrem. 2012. Mestrer Mestrer Ikke. Jakten på det Normale Barnet. Oslo: Res Publica.

Reay, Diane. 1998. Re-thinking social class: qualitative perspectives on class and gender. Sociology 32: 259-75. [CrossRef]

Sakslind, Rune. 2007. Kunnskap og klasseanalyse: Middelklasseproblemet og samfunnsformasjonen. In Arbeid, Kunnskap og Sosial Ulikhet. Edited by Hjellbrekke Johs, Olsen Ole Johnny and Rune Sakslind. Oslo: Unipub, pp. 221-56.

Sakslind, Rune, and Ove Skarpenes. 2014. Morality and the middle class. The European pattern and the Norwegian singularity. Journal of Social History 48: 313-40. [CrossRef]

Sakslind, Rune, Tor Halvorsen, and Olav Korsnes. 1985. Arbeidslivsforskning og de særegne industrielle relasjoner i Norge. Norsk arbeidsliv i komparativt perspektiv. In Politikkens Forvaltning. Edited by Bleiklie Ivar. Oslo: Universitetsforlaget, pp. 42-73.

Savage, Mike. 2000. Class Analysis and Social Transformation. Buckingham: Open University Press.

Savage, Mike. 2015. Social Class in the 21st Century. Great Britain: Penguin Books. Great Britain: Penguin Books.

Savage, Mike, and Tony Bennett. 2005. Editors' introduction: Cultural Capital and Social Inequality. The British Journal of Sociology 56: 49-64. [CrossRef] [PubMed]

Savage, Mike, and Andrew Miles. 1994. The Remaking of the British Working Class 1840-1940. London and New York: Routledge.

Savage, Mike, Gaynor Bagnall, and Brian Longhurst. 2001. Ordinary, Ambivalent, and Defensive: Class. Identities in the Northwest of England. Sociology 35: 875-92. [CrossRef]

Sejersted, Francis. 1993. Demokratisk Kapitalisme. Oslo: Universitetsforlaget.

Sejersted, Francis. 2005. Sosialdemokratiets Tidsalder: Norge og Sverige i det 20. Århundre. Oslo: Pax.

Seljestad, Lars Ove. 2003. Frisatt eller forankra? Sosiolog-Nytt 28: 7-18.

Skarpenes, Ove. 2007a. Kunnskapens Legitimering. Fag og Læreplaner i Videregående Skole. Oslo: Abstrakt forlag.

Skarpenes, Ove. 2007b. Den 'legitime kulturens' moralske forankring. Tidsskrift for Samfunnsforskning 48: 531-63.

Skarpenes, Ove, and Ann Christin Eklund Nilsen. 2014. Making up pupils. Norsk Pedagogisk Tidsskrift 6: 424-39.

Skarpenes, Ove, and Rune Sakslind. 2018. Educational Experiences and Perceptions of Occupational Hierarchies: The Case of the Norwegian Working Class, For Review.

Skeggs, Beverly. 1997. Formations of Class \& Gender: Becoming Respectable. London: SAGE Publications.

Skilbrei, May-Len. 2010. Den som står med begge beina planta på jorda står stille: Om Kjønn og klassereiser. In Klassebilder Ulikhet og Sosial Mobilitet $i$ Norge. Edited by Kenneth Dahlgren and Jørn Ljunggren. Oslo: Universitetsforlaget.

Somers, Margaret. 1997. Deconstructing and Reconstructing Class Formation Theory: Narrativity, Relational Analysis, and Social Theory. In Reworking Class. Edited by John Hall. Ithaca and London: Cornell University Press. 
Vogt, Kristoffer Celsom. 2007. Gutter i Mannsdominerte Yrkesfag: Valg av Utdanning og Arbeid. Master thesis, Departement of Socioolgy, University of Bergen, Bergen, Norway.

Olivier Zunz, Leonard Schoppa, and Nobuhiro Hiwatari, eds. 2002. Social Contracts under Stress. The Middle Classes of America, Europe, and Japan at the Turn of the Century. New York: Russell Sage Foundation.

(c) 2018 by the authors. Licensee MDPI, Basel, Switzerland. This article is an open access article distributed under the terms and conditions of the Creative Commons Attribution (CC BY) license (http://creativecommons.org/licenses/by/4.0/). 